\title{
Comparison of the Disturbance of Soil Physical Quality Indices Between Different Underground Mining Stages in Semi-Arid Regions of Western China
}

Dejun Yang ( $\nabla$ yangdj81@163.com)

China University of Mining and Technology https://orcid.org/0000-0002-1090-5722

BIAN Zhengfu

China University of Mining and Technology - Xuzhou Campus: China University of Mining and Technology

\section{Research Article}

Keywords: cumulative probability, support resistance, soil cohesion, soil physical quality, soil water content, underground mining

Posted Date: June 16th, 2021

DOI: https://doi.org/10.21203/rs.3.rs-524144/v1

License: () (7) This work is licensed under a Creative Commons Attribution 4.0 International License. Read Full License 


\section{Abstract}

Based on soil sampling, lab experiment and support resistance monitoring, the disturbance of soil physical quality indices between different underground mining stages of No 52303 working face was studied in semi-arid region of western China. Soil sampling was conducted in same locations before and after mining in 2014. This study proved that soil water content, soil cohesion and soil porosity were greatly decreased, while bulk density and dry density were increased by coal mining. In comparison, coal mining had slight effect on organic matter, internal fraction angle, and D1 and D2 percent. Underground pressure monitoring showed that P1 during stage 2 was significantly greater than that during stage 1, indicating the large difference of pressure characteristics in tail areas of working face between two stages. Both soil water content and soil cohesion were decreased during two stages in two sites. Soil cohesion was strongly correlated to soil water content, and D1 and D2 percent in 2013 and 2014. Coal mining subsidence increased the cumulative probability to reach the same value of soil water content and soil cohesion. The cover depth produced different elastic and plastic zone widths between sites by theoretical model calculation, consistent with the support resistances in tail areas of working face. Higher pressure might cause a more serious destructive rock-soil body and a larger groundwater level decrease. The dryer and more serious erosive soil column induced by coal mining is a non negligible matter for the semi-arid region.

\section{Introduction}

Nowadays, 14 major coal bases (including 98 mining areas) in China locate in Shanxi, Shaanxi, Inter Mongolia, Ningxia, Gansu and Xinjiang provinces in semi-arid regions of western China. These areas are mainly covered by loess and aeolian sand, with shallow burial, thin bedrock, thick coal seam and relatively simple geological conditions. Its eco-environment is vulnerable, characterized of serious soil erosion and poor ecological restoration ability. However, coal production in these areas accounts for more than $75 \%$ of the total amount in China (Liu et al. 2015, Yang et al. 2016).

About $85 \%$ of China's coal production comes from underground coal mining. The eco-environmental influences induced by underground coal mining have been well documented in Bian et al. (2010), Bian et al. (2012), Huang et al. (2014), Jing et al. (2018), Kuter et al. (2014), Qiu et al. (2019), Ristović (2010), Wang et al. (2017), Xiao et al. (2019), Yang et al. (2016), Yang et al. (2018) and Yang et al. (2019). These influences can be restored through land reclamation and ecological restoration measures, which have been proved to be an effective way to restore the destructive environment in mining areas (Heras et al. 2011, Krümmelbein and Raab 2012, Mukhopadhyay et al. 2013, Qiu et al. 2019, Xiao et al. 2019). Land subsidence, as one of the significant influences by underground coal mining, will not only change soil quality but also cause many other eco-environmental problems (Huang et al. 2014, Kuter et al. 2014, Qiu et al. 2019, Wang et al. 2017, Yang et al. 2016, Yang et al. 2018, Yang et al. 2019). Statistics showed that 10,000 tons raw coal production would averagely lead to 0.2 hectares subsided lands in China (Bian et al. 2010). The land area induced by coal mining subsidence is currently $700,000 \mathrm{~km}^{2}$ and is continually increasing at a rate of $130 \mathrm{~km}^{2}$ annually (Wang et al. 2016).

Soil physical quality, acting as the central role among soil qualities, has big effect on soil physical, chemical and biological processes (Dexter 2004). Soil cohesion (SC) is an important soil physical quality index, for its strong relationships with soil water content (SWC) (Arvidsson and Keller 2011), soil detachment capacity (Li et al. 2015a), organic manures (Hemmat et al. 2010) and soil shear strength (Yang et al. 2016). It was found that the saturated shear strength could be considered as the best soil property to predict critical shear stress and runoff erosion (Léonard and Richard 2004).

There are still needs to study whether soil physical quality indices change with land subsidence, and to what extent they are disturbed by different mining intensity. To better understand soil physical quality before and after mining and during reclamation process, numerous studies have been conducted in past few decades. They include the study on the bulk density, pore size distribution and saturated hydraulic conductivity in Krümmelbein and Raab (2012), the hydrological response of reclaimed mining soils in Heras et al. (2009), the temporal availability and spatial distribution of soil moisture in Heras et al. (2011), the infiltration rate at reclaimed surface coal mines (Reynolds and Reddy 2012), the soil moisture and groundwater table in Shendong coal mining (Bian et al. 2009), the effect on soil physical quality indices (Yang et al. 2016), vegetation and environmental patterns (Yang et al. 2018) and soil nitrogen (Yang et al. 2019) induced by land subsidence, the chemical properties and enzyme activities of rhizosphere ameliorated by Arbuscular mycorrhizal fungi (Qiu et al. 2019), the soil enzyme activities and microbial biomass by re-vegetation type and arbuscular mycorrhizal fungal inoculation (Xiao et al. 2019) and the spatial and temporal variations of SWC in semi-arid mining area (Wang et al. 2017).

The loess region of western China, abundant in high quality coal resources, is characterized by the vulnerable ecological environment and semi-arid climate. It is likely the most severely eroded region in the world (Jing et al. 2018, Li et al. 2015a). By the end of 2015, the subsided lands increased to 314 km², accounting for $26.2 \%$ of the Shenfu-Dongsheng coal field areas, which locates in the loess region (He et al. 2017). To keep the balance between coal resource exploitation and environmental protection, some studies have been conducted in this area. It concluded that the soil detachment capacity was negatively correlated with sand content, SC, soil water stable aggregate, soil aggregate median diameter, organic matter, and root density for the red and yellow loess soils in the loess plateau of China (Li et al. 2015b). Coal mining subsidence had little effect on plant diversity and community structure, characterized as an intermediate disturbance to plant communities in Daliuta coal mine (He et al. 2017). Some studied showed that underground mining activities had negative impacts on SWC for both small and large scale coal mining areas (Wang et al. 2017) and SWC suffered the worst effects from mining activities (Zang et al. 2010).

Underground mining activities are a particular concern where the need to extract coal resources can lead to conflicts among miners, farmers, and the general public (Yang et al. 2018). The local government and residents also ask the companies to take responsibility for reclamation (Yang et al. 2016). Coal mining companies must be responsible to take measures to restore the destructive environment, especially for the vulnerable semi-arid mining areas. Based on the cumulative probability theory, Yang et al (2016) concluded that coal mining could decrease SWC, SC and organic matter and increase internal fraction angle for the loess soil of the land above the No. 52303 working face in 2013. The follow-up soil sampling and lab experiments were still carried out along the land 
above this working face in 2014. The monitoring for underground mining was conducted synchronously in 2013 and 2014 , providing more detailed parameters for this working face and many useful intensity parameters for mining process (Hao 2015, Zhu et al. 2017, Zhu et al. 2019a, Zhu et al. 2019b).

The high stresses caused by deep mining are the dominant factor leading to the occurrence of strong mine pressure on roadways (He et al. 2005). Severe strata breakage and movement during extraction lead to strong mine pressure in working faces (Zhu et al. 2019b). In the No 52303 working face, strong strata behaviour such as roof collapse and sudden roof subsidence have occurred at the working face-end and caused serious destruction of soil physical quality. Hao $(2015)$ and Zhu et al $(2017,2019 b)$ introduced three-stages theory for the mining process of the No 52303 working face, according to cover depth, support resistance, number of pressure, average periodic pressure step, dynamic load coefficient, pressure duration length and destructive behavior. Thus, the scientific issue of what law the change of soil physical quality indices follows during different mining stages will promisingly be studied. What is more, to what extent soil physical quality indices are disturbed by different mining stages may be better understood.

In these regards, more studies will be required to better understand the above issues, especially for the semi-arid area such as the loess region. To the best of our knowledge, up to now, no documentation was found to study the disturbance of soil physical quality indices for different mining intensity in same working face. Hence, the objectives of this study were to (1) investigate the impact on soil physical quality indices in 2014, (2) make comparisons of soil physical quality between different mining stages, and (3) reveal the possible reasons for the disturbance of soil physical quality indices induced by different underground mining intensity in the loess region of western China.

\section{Materials And Methods}

\subsection{The study area and No 52303 working face}

The study area was located in Daliuta mining area, Shanxi Province, belonging to the border of Shanxi, Shaanxi and Inter Mongolia provinces, between $39.1^{\circ}$ to $39.4^{\circ} \mathrm{N}$ longitudes and between $111.2^{\circ}$ to $110.5^{\circ} \mathrm{E}$ latitudes (Yang et al 2016, Yang et al 2019). Details (including topography, geomorphology, meteorology, hydrology, soil and vegetation) were available in Yang et al. (2016), Yang et al. (2019) and Zhu et al. (2019b).

The fully mechanized longwall working face (No 52303) was the second mining face of the No. 3 district in the No. 5 - 2 coal seam in Daliuta mining area of Shenhua Shendong Coal Group (Yang et al. 2016, Zhu et al. 2019b). The land surface was mainly covered by quaternary loose sediments. The bedrock outcrops could be seen in gully areas and the gully development areas in the middle working face was thinner (Zhu et al. 2019b). No faults, scour bodies or other structures were found in the tunnelling process of the gate roadway of the working face (Zhu et al. 2019b). Details of the working face could be seen in Table 1.

Table 1

Details of the No. 52303 working face (Yang et al. 2016; Zhu et al. 2019)

\begin{tabular}{|c|c|c|c|c|c|c|c|}
\hline Working Face & $\begin{array}{l}\text { Coal } \\
\text { Seam }\end{array}$ & Panel & $\begin{array}{l}\text { Ground } \\
\text { Elevation/m }\end{array}$ & $\begin{array}{l}\text { Floor } \\
\text { Elevation/m }\end{array}$ & $\begin{array}{l}\text { Cover Depth of Coal } \\
\text { Seam } / \mathrm{m}\end{array}$ & $\begin{array}{l}\text { Thickness of } \\
\text { Overlying } \\
\text { Bedrock/m }\end{array}$ & $\begin{array}{l}\text { The Length of } \\
\text { Working Face/m }\end{array}$ \\
\hline No.52303 & $5^{-2}$ & 3 & $\begin{array}{l}1162.40 \sim \\
1255.30\end{array}$ & $985.13 ه 1020.99$ & $173.00 \sim 282.00$ & $132.00 \sim 245.00$ & 4443.30 \\
\hline $\begin{array}{l}\text { The Width of } \\
\text { Working Face/m }\end{array}$ & Area/m² & $\begin{array}{l}\text { The Thickness of } \\
\text { Coal Seam } / m\end{array}$ & Dip Angle/ ${ }^{\circ}$ & $\begin{array}{l}\text { Bulk } \\
\text { Density } /\left(\mathrm{g} / \mathrm{cm}^{3}\right)\end{array}$ & $\begin{array}{l}\text { The Thickness of } \\
\text { Surface Soil } \\
\text { Layer } / \mathrm{m} /\end{array}$ & $\begin{array}{l}\text { The Average } \\
\text { Mining } \\
\text { Rate/(m/d) }\end{array}$ & $\begin{array}{l}\text { Designed } \\
\text { Mining } \\
\text { Height/m }\end{array}$ \\
\hline 301.50 & 1339700 & $6.60 \sim 7.30$ & $1^{\circ} \sim 3^{\circ}$ & 1.29 & 30.00 & 10.00 & 6.60 \\
\hline
\end{tabular}

The hydraulic support (ZY18000/32/70) made by Zhengzhou Coal Mine Company and the shearer (SL1000) made by EKF company were equipped. The support height was $3200 \sim 7000 \mathrm{~mm}$ and the center distance between supports was $2.05 \mathrm{~m}$. The diameter of the roller was $3500 \mathrm{~mm}$ and the cutting depth was $865 \mathrm{~mm}$. Pressure gauge and pressure automatic monitoring system were installed in each support column of working face. Data could be automatically recorded and transmitted by PM31 support resistance on-line monitoring system. Uroica pressure monitoring sensor was installed on every 10 supports for data acquisition and recording. The process of the measured data collecting was carried out via Uroica pressure recorder, PM31 support resistance online monitoring system and column pressure gauge.

At the first normal mining pressure stage along the goaf, the cover depth was less than $250 \mathrm{~m}$ and the advancing distance was $0 \sim 3492 \mathrm{~m}$ (from the working face cut to No 25 connection roadway (CR)) (Stage 1). At the strong mining pressure stage along the goaf, and the cover depth was more than $250 \mathrm{~m}$ and the advancing distance was $3492 \sim 4155 \mathrm{~m}$ (from No 25 to $11 \mathrm{CR}$ ) (Stage 2). At the second normal mining pressure stage along the solid coal side, the cover depth was more than $250 \mathrm{~m}$ and the advancing distance was $4155 \sim 4405 \mathrm{~m}$ (from No 11 CR to the withdrawal channel) (Stage 3) (Hao 2015).

\subsection{The soil sampling and lab experiments}

In 2013, we designed the distribution of soil sampling locations on the site above No 35 39 CR (Site 1) according the horizontal movement and deformation theory of mining subsidence (He et al. 1991, Yang et al. 2016). 21 sampling locations (including 5 locations within external pulled zone, 6 locations within internal pulled zone, 5 locations within compressed zone and 5 locations within neutral zone) were lay out. The sampling time before mining was from September, 09 to 11, 2013, and that after mining was from November, 06 to 08,2013 . In 2014, 42 sampling locations were distributed averagely on the site above No $11 \sim 15$ CR (Site 2). The sampling time before mining and after mining was from March, 19 to 23, 2014, and from May, 19 to 25, 2014 , respectively. All soil sampling depths were within $0.05 \mathrm{~m} \sim 0.15 \mathrm{~m}$. SC and internal fraction angle were determined by the consolidated slow shear test (Price 2009 ). Organic 
matter was measured using the potassium dichromate colorimetric method (Li et al. 2015a). The bulk density, dry density, SWC and porosity was measured by the oven-drying method.

\subsection{The theory}

Soil shear strength is quantified by two-component Mohr-Coulomb criterion and expressed in Eq. (1) (Johnson et al. 1987, Koolen and Kuipers 1983, Yang et al. 2016) :

$$
\tau=c+\sigma_{n} \tan \varphi \quad(1)
$$

Where $\tau$ is the soil shear strength, $\mathrm{kPa} ; c$ is the soil cohesion, $\mathrm{kPa} ; \sigma_{n}$ is the normal stress acting on the failure surface, $\mathrm{kPa} ; \varphi$ is the internal fraction angle, ${ }^{\circ}$. The cumulative probability of a discrete distribution is the probability that the variable takes a value less than or equal to $x$, and expressed in Eq. (2) (Gentle 2009, Yang et al. 2016):

$$
F(x)=P(X \leq x)=\sum_{x_{i} \leq x} p\left(x_{i}\right)
$$

Where $F(x)$ is the cumulative probability or cumulative distribution function; $P(X \leq x)$ is the probability that the variable takes a value less than or equal to $X$, $p\left(x_{i}\right)$ is the probability density function which is the probability that the variable has the value $x_{i} . p\left(x_{i}\right)$ is calculated in Eq. (3) (Gentle 2009, Yang et al. 2016):

$$
p\left(x_{i}\right)=p\left(x=x_{i}\right)
$$

According to the limit equilibrium theory, the plastic zone width of coal pillar mined on one side, $x_{0}$, is expressed in Eq. (4) (Gao 2014, Zhu et al. 2017, Zhu et al. 2019b):

$$
x_{0}=\frac{M A}{2 \tan \varphi_{0}} \ln \left(\frac{k \gamma H+\frac{C_{0}}{\tan \varphi_{0}}}{\frac{C_{0}}{\tan \varphi_{0}}+\frac{P_{z}}{A}}\right)
$$

where $M$ is the mining height of the working face, $\mathrm{m} ; A$ is the coefficient of horizontal pressure; $\varphi_{0}$ is the internal friction angle of coal pillar, ${ }^{\circ} k$ is the stressconcentration factor; $y$ is the average unit weight of the overlying strata, $\mathrm{MN} / \mathrm{m}^{3} ; H$ is the cover depth of the working face; $C_{0}$ is the cohesion coefficient of the coal mass, $\mathrm{MPa} ; P_{z}$ is the support resistance of the roadway, MPa.

A disturbance factor of 1.2 was considered for the No 52303 working face and the plastic zone width of coal pillar mined on both sides, $x$, can be expressed in Eq. (5) (Zhu et al. 2017, Zhu et al. 2019b):

$x=x_{0}+1.2 x_{0}=2.2 x_{0}$

The parameterization were: $M=7 \mathrm{~m}, A=0.8, C_{0}=1.4 \mathrm{MPa}, \varphi_{0}=30^{\circ}, k=2.0, \gamma=0.025 \mathrm{MN} / \mathrm{m}^{3}$ and $P_{Z}=0.3 \mathrm{MPa}$ (Hao 2015, Zhu et al. 2017, Zhu et al. 2019b). The relationships between cover depth and elastic and plastic zone widths for No 52303 working face during different stages were shown in Fig. 1. The cover depth was $185 \sim 199 \mathrm{~m}$ on site 1 and $257 \sim 264 \mathrm{~m}$ on site 2, respectively. The elastic and plastic zone widths were $4.14 \sim 4.77 \mathrm{~m}$ and $15.23 \sim 15.86 \mathrm{~m}$ on site 1 for stage 1 , and $1.66 \sim 1.90 \mathrm{~m}$ for $18.10 \sim 18.34 \mathrm{~m}$ on site 2 for stage 2 . With the increase of cover depth, the plastic zone width increased significantly, while the elastic zone width decreased accordingly.

\subsection{The statistical analysis}

The descriptive statistical indices including mean, minimum, maximum, sample variance (SV), sample standard deviation (SSD) and coefficient of variation (CV) were used for the statistical analysis of soil physical quality.

\section{Results}

\subsection{Comparisons of soil physical quality indices before and after mining during stage 2 in 2014}

The nine soil physical quality indices before and after mining was different during stage 2 in 2014 (Fig. 2). For SWC and soil porosity, most values after mining were less than those before mining, which led the trend line completely under the line $Y=X$. The trend line was mostly under the line $Y=X$ for $S C$, however, the number of measured points under the line $Y=X$ was approximately equal to that above the line $Y=X$. It was also shown that the average SWC, soil porosity and SC were obviously reduced by coal mining (Table 2). For bulk density and dry density, there were more measured points above the line $\mathrm{Y}=\mathrm{X}$, indicating an increase trend of these two indices after mining. For organic matter, internal fraction angle, and D1 (0.25 $0.075 \mathrm{~mm})$ and D2 (0.075 0.005 $\mathrm{mm}$ ) percent, the measured points distributed averagely on both sides of $Y=X$. The average values of these four indices before and after mining were approximately equal (Table 2), which indicated that the influence on these four indices by coal mining was not obvious. 
Table 2

The descriptive statistical index for different soil physical quality index in 2013 and 2014

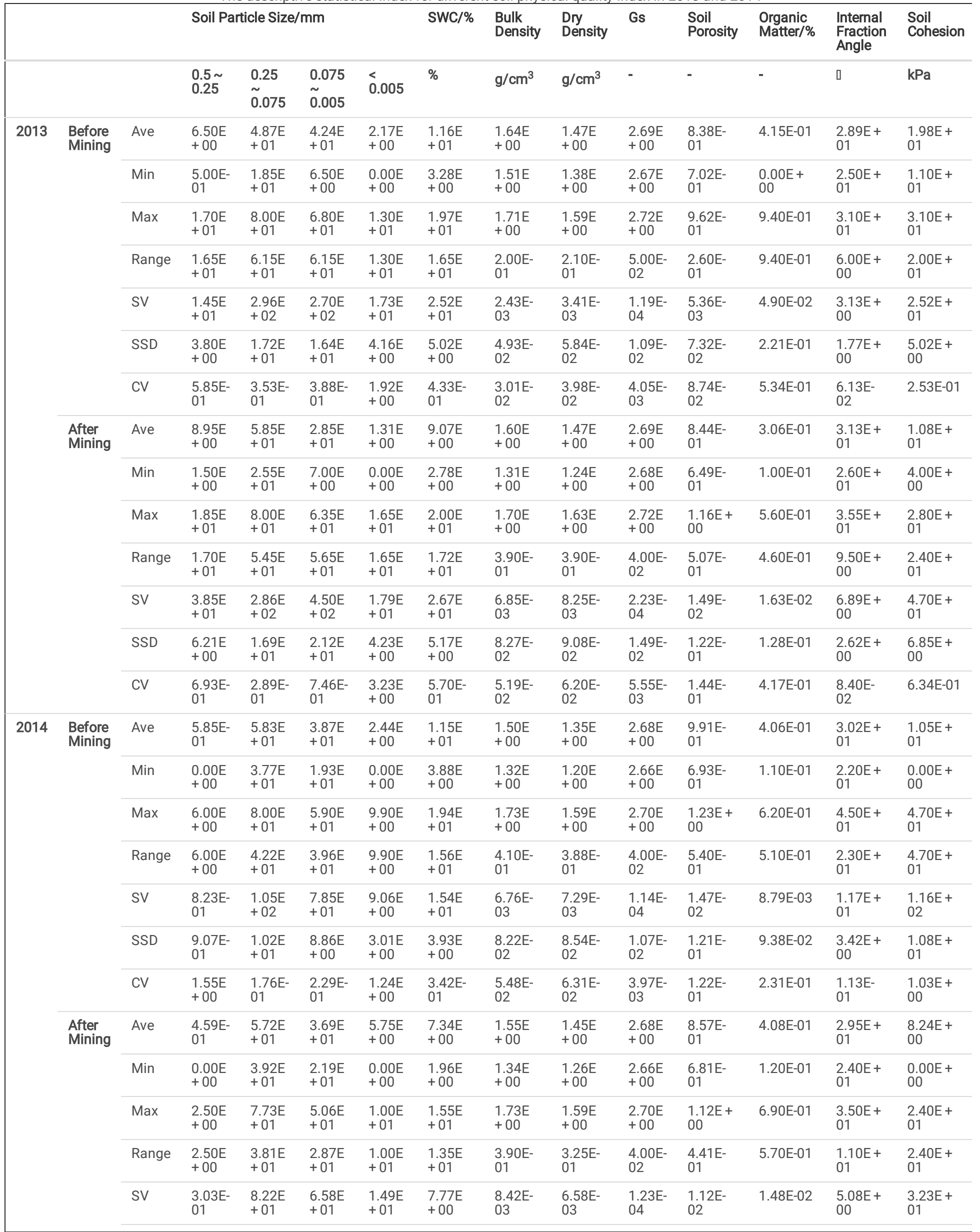




\begin{tabular}{|lllllllllllll}
\hline & \multicolumn{1}{cl}{ Soil Particle Size/mm } & & SWC/\% & $\begin{array}{l}\text { Bulk } \\
\text { Density }\end{array}$ & $\begin{array}{l}\text { Dry } \\
\text { Density }\end{array}$ & Gs & $\begin{array}{l}\text { Soil } \\
\text { Porosity }\end{array}$ & $\begin{array}{l}\text { Organic } \\
\text { Matter/\% }\end{array}$ & $\begin{array}{l}\text { Internal } \\
\text { Fraction } \\
\text { Angle }\end{array}$ & $\begin{array}{l}\text { Soil } \\
\text { Cohesion }\end{array}$ \\
\hline
\end{tabular}

Although the on-site sampling was conducted on the same locations before and after mining, the high temporal and spatial variations led the correlation coefficients low in Fig. 2. Only the correlation coefficients of SWC, SC, bulk density, D1 and D2 were greater than 0.10. SWC, soil porosity, SC, bulk density and dry density were all greatly influenced by coal mining subsidence during stage 2 in 2014 . The first three indices were decreased, while the others were increased.

\subsection{The relationships between SC and other indices before and after mining during stage 2 in 2014}

With the increase of SWC, SC generally increased before and after mining (Fig. 3A). The positive relationships were consistent with Hemmat et al. (2010) and Yang et al. (2016), but opposite to Arvidsson and Keller (2011) and Fan and Su (2008). This was mainly attributed to different SWC range and soil type as discussed in Yang et al. (2016). The minimum and maximum of SWC were $1.96 \%$ and $19.4 \%$ in 2014 and were very close to $2.78 \%$ and $20.0 \%$ in 2013 (Yang et al. 2016). In Hemmat et al. (2010), SC was about doubled when SWC increased from $17.1 \%$ to $20.9 \%$. Soils with four different clay contents showed a strong negative correlations between SC and SWC because most SWCs were within $20 \%$ to $40 \%$ in Arvidsson and Keller (2011).

The SC had a slight increase trend with the decrease of D1 percent (Fig. 3G) and the increase of D2 percent (Fig. 3H) in 2014, although the R ${ }^{2}$ were relative lower. On site 2, D1 and D2 were the main component of soil particles, altogether occupying for $91.90 \%$ before mining and $87.0 \%$ after mining. More large particles (or less small particles) made the soil column more porous, causing soil column loosening and SC decreasing. The fitting lines after mining (Fig. $3 \mathrm{G}$, 3H) were both under those before mining in 2014.

The relationships between SC and bulk density before and after mining in 2014 showed a slight positive trend (Fig. 3D). The soil with larger bulk density would lead SC larger. However, the relationships between SC and internal fraction angle (Fig. 3B), organic matter (Fig. 3C), dry bulk (Fig. 3E) and porosity (Fig. 3F) before mining were opposite to those after mining in 2014.

\subsection{The pressure characteristics of supports in $\mathbf{5 2 3 0 3}$ working face for two stages}

The differences of pressure characteristics in head area (No $1 \sim 20$ support) and middle area (No $30 \sim 120$ support) of the working face between two stages were little (Table 3). For No $1 \sim 20$ support, the end-of-cycle resistance of support (P1) was kept below $12000 \mathrm{kN}$, which was close to the initial support force. For No 20 support, P1 and the end-of-cycle resistance of support during non-weighting period (P2) were 13364kN and 11304kN for stage 1, and 13953 kN and $11656 \mathrm{kN}$ for stage 2 , with only $4.2 \%$ and $3.0 \%$ increase rate. The dynamic load coefficient increased from 1.18 to 1.20 , while weighting duration distance increased from $1.60 \mathrm{~m}$ to $1.80 \mathrm{~m}$ ( $11.1 \%$ increase rate) from stage 1 to 2 . There was no rib spalling and leakage phenomenon in head areas of two stages, with no safety valves opening. In middle areas, the average P1 and P2 were $17952 \mathrm{kN}$ and $11563 \mathrm{kN}$ for stage 1 , and $17561 \mathrm{kN}$ and $11267 \mathrm{kN}$ for stage 2 , with $2.2 \%$ and $2.6 \%$ decrease rate. The dynamic load coefficient increased from 1.55 to 1.56 , while weighting duration distance decreased from $5.5 \mathrm{~m}$ to $5.4 \mathrm{~m}$ from stage 1 to 2 . The rib spalling and leakage phenomenons appeared in middle areas of two stages, with $60 \%$ 70\% safety valves opening. 
Table 3

The statistics of pressure characteristics of supports in 52303 working face (Hao 2015)

\begin{tabular}{|c|c|c|c|c|c|c|c|}
\hline & $\begin{array}{l}\text { Support } \\
\text { No }\end{array}$ & $\begin{array}{l}\text { Times of } \\
\text { periodic } \\
\text { weighting }\end{array}$ & $\begin{array}{l}\text { Average } \\
\text { periodic } \\
\text { weighting } \\
\text { interval/m }\end{array}$ & $\begin{array}{l}\text { Average end-of-cycle resistance } \\
\text { of support during weighting } \\
\text { period/kN (P1:) }\end{array}$ & $\begin{array}{l}\text { Average end-of-cycle resistance of } \\
\text { support during non-weighting } \\
\text { period/kN (P2) }\end{array}$ & $\begin{array}{l}\text { Dynamic } \\
\text { load } \\
\text { coefficient }\end{array}$ & $\begin{array}{l}\text { Weighting } \\
\text { duration } \\
\text { distance/m }\end{array}$ \\
\hline \multirow[t]{14}{*}{ Stage } & 1 20\# & \multicolumn{6}{|c|}{$\begin{array}{l}\text { The average end-of-cycle resistance of support was kept below } 12000 \mathrm{kN} \text {, which was close to the initial support force. There was no } \\
\text { significantly serious ground pressure behavior in working face, such as rib spalling, roof falling and leakage phenomenon.** }\end{array}$} \\
\hline & $20 \#$ & 7 & - & 13364 & 11304 & 1.18 & 1.6 \\
\hline & $30 \#$ & 21 & 17.3 & 17967 & 11443 & 1.57 & 5.3 \\
\hline & $40 \#$ & 21 & 16.9 & 17818 & 11545 & 1.54 & 5.1 \\
\hline & $50 \#$ & 21 & 17.7 & 17962 & 11867 & 1.51 & 6.2 \\
\hline & $60 \#$ & 21 & 17.7 & 18109 & 11510 & 1.57 & 6.3 \\
\hline & 70\# & 21 & 17.5 & 18080 & 11690 & 1.55 & 5.7 \\
\hline & $80 \#$ & 21 & 17.8 & 17670 & 11132 & 1.59 & 5.1 \\
\hline & $90 \#$ & 21 & 17.0 & 18089 & 12061 & 1.50 & 5.5 \\
\hline & $100 \#$ & 21 & 16.8 & 17993 & 11894 & 1.51 & 5.3 \\
\hline & $110 \#$ & 21 & 17.8 & 17902 & 11262 & 1.59 & 6.0 \\
\hline & $120 \#$ & 21 & 18.1 & 17933 & 11223 & 1.60 & 5.2 \\
\hline & $130 \#$ & 5 & - & 13776 & 11480 & 1.20 & 1.2 \\
\hline & $130 \sim$ & \multicolumn{6}{|l|}{ Same as ** } \\
\hline \multirow{16}{*}{$\begin{array}{l}\text { Stage } \\
2\end{array}$} & 1 20\# & \multicolumn{6}{|l|}{ Same as ** } \\
\hline & $20 \#$ & \multicolumn{2}{|l|}{10} & 13953 & 11656 & 1.20 & 1.8 \\
\hline & $30 \#$ & 19 & 15.4 & 17368 & 12540 & 1.39 & 4.8 \\
\hline & 40\# & 19 & 15.2 & 17662 & 11480 & 1.54 & 5.3 \\
\hline & $50 \#$ & 19 & 15.7 & 17576 & 11655 & 1.51 & 5.2 \\
\hline & $60 \#$ & 19 & 15.9 & 17909 & 11510 & 1.56 & 6.0 \\
\hline & $70 \#$ & 19 & 16.3 & 17073 & 10303 & 1.66 & 5.5 \\
\hline & $80 \#$ & 19 & 15.3 & 17670 & 11132 & 1.59 & 5.3 \\
\hline & 90\# & 19 & 15.7 & 17368 & 11892 & 1.46 & 4.9 \\
\hline & $100 \#$ & 19 & 15.4 & 17250 & 10479 & 1.65 & 5.1 \\
\hline & 110\# & 19 & 16.0 & 17902 & 11262 & 1.59 & 6.0 \\
\hline & $120 \#$ & 19 & 15.2 & 17839 & 10420 & 1.71 & 5.7 \\
\hline & $130 \#$ & 19 & 15.8 & 16427 & 11721 & 1.40 & 2.2 \\
\hline & $135 \#$ & 14 & 20.6 & 16308 & 11716 & 1.39 & 1.6 \\
\hline & $140 \#$ & 9 & & 14188 & 11578 & 1.23 & 1.3 \\
\hline & $\begin{array}{l}140 \sim \\
150 \#\end{array}$ & \multicolumn{6}{|l|}{ Same as ** } \\
\hline
\end{tabular}

However, the differences of pressure characteristics in tail area (No $130 \sim 150$ support) of working face were very large for two stages (Table 3). During stage 1, P1 was kept below 12000 kN, with no rib spalling and leakage phenomenon appearance. In comparison, P1 was still kept below 12000 kN for No 140 150 , but more than $14000 \mathrm{kPa}$ for No 130, 135 and 140 support during stage 2 (Table 3). The incidents including roof collapse and coal-wall rib spalling were very severe. In tail areas, the P1 during stage 2 was significantly more than that during stage 1 (Fig. 4). Figure 4 showed the whole comparison of support resistances between stage 1 and 2 .

\section{Discussion}

\subsection{Comparisons of the impact on soil physical quality indices between two stages}


Since the impact on soil physical quality indices during stage 1 in 2013 (Supplemental materials 1) were documented (Yang et al. 2016), only the comparison of the impact on soil physical quality indices between two stages would be discussed. The average SWC decreased from $11.6 \%$ to $9.07 \%$ for stage 1 and from $11.5 \%$ to $7.34 \%$ for stage 2 . The average SC decreased from $19.8 \mathrm{kPa}$ to $10.8 \mathrm{kPa}$ for stage 1 and from $10.5 \mathrm{kPa}$ to $8.24 \mathrm{kPa}$ for stage 2 . Both SWC and $\mathrm{SC}$ were greatly reduced by coal mining activities for two stages. The average bulk density and dry density after mining were less than those before mining in 2013 , however, these decreased during stage 2 in 2014 . The different impact on soil bulk and dry density between two stages led the impact on soil porosity different.

The average organic matter were slightly increased from $0.406 \%$ to $0.408 \%$ during stage 2 in 2014 , which was opposite to the large decrease (from 0.415 to $0.306 \%$ ) during stage 1 in 2013. The impact on internal fraction angle, D1 and D2 were also found opposite between two stages. The different impacts on the four indices for two stages were possibly attributed to the soil temporal and spatial variations and the slight influence of coal mining activities.

\subsection{Comparisons of the relationships between $\mathrm{SC}$ and other indices for two stages}

Generally, the strong relationships between SC and SWC, and D1 and D2 percent were found for both 2013 (Supplemental materials 2) and 2014 (Fig. 3). In 2014 , the fitting liner curve (SC-SWC) before mining was $y=0.91 x+0.057$, while it was $y=0.77 x+2.59$ after mining. The slopes of the fitting lines in 2014 were close to those in 2013 ( 0.65 before mining and 1.23 after mining). However, the $\mathrm{R}^{2}$ of the fitting lines in 2014 were less than those in 2013 . For loess soils, SC was sensitive to SWC (Wilson et al. 2013, Yang et al. 2016) and SWC might be the most sensitive index that decided SC. For the loess soils of site 1 and 2 , SWC and SC were both positively correlated and were influenced to reduce by coal mining subsidence.

A negative correlation (SC-D1) and a positive correlation (SC-D2) were found before and after mining in 2013 (Supplemental material $2 \mathrm{G}$ and $2 \mathrm{H}$ ), with the relative higher $\mathrm{R}^{2}$ being over 0.50 . D1 was within $18.5-80.0 \%$ in 2013 and within $37.1-80.0 \%$ in 2014 , while D2 was within $6.5-68.1 \%$ in 2013 and within 19.3-59.0\% in 2014 (Table 2). The difference of $R^{2}$ between 2013 and 2014 were mainly attributed to the range of soil particle size. The wider range of $D 1$ and D2 percent in 2013 made $\mathrm{R}^{2}$ higher. Similar with 2014, the fitting lines (SC-D1 and SC-D2) after mining were both under those before mining in 2013 (Supplemental material $2 \mathrm{G}$ and $2 \mathrm{H}$ ).

The slight positive trends were found for the relationship (SC-bulk density) before and after mining in 2013 and 2014 . The relationships (SC-internal fraction angle, SC-organic matter, SC-dry density and SC-porosity) in 2013 were all found different from those in 2014. This reproved that coal mining subsidence had slight effect on these indices.

\subsection{The cumulative probability of SC, SWC, internal fraction angle, and organic matter before and after mining in 2013 and 2014}

For the same cumulative probability, most values of SC and SWC after mining were less than those before mining (Fig. 5A and 5B). It was reproved that SWC and SC were greatly influenced to decrease by coal mining subsidence (Yang et al. 2016). It was concluded that the influences of coal mining subsidence increased the cumulative probability to reach the same value of SWC and SC. While it was found that subsidence increased the cumulative probability of organic matter in 2013, the measurement in 2014 showed an opposite phenomena (Fig. 5C). The opposite phenomena occurred on internal fraction angle as well (Fig. 5D). These phenomena could also illustrated by the average organic matter and internal fraction angle in Table 2.

\subsection{The impact on soil physical quality indices by different pressure characteristics for two stages}

The strata behaviour of working face was closely related to the working resistance of supports, surrounding geological conditions and mining parameters ( $\mathrm{Li}$ et al. 2018; Masoud et al. 2016; Zhu et al. 2019a). The cover depth during stage 1 was within 137 to $230 \mathrm{~m}$, with the average elastic zone width being $4.70 \mathrm{~m}$. In comparison, the cover depth during stage 2 was within 245 to $264 \mathrm{~m}$, with the average elastic zone width being only $2.05 \mathrm{~m}$. In Zhu et al (2019b), field measurements and statistical analyses suggested that the critical cover depth value to prevent strong strata behaviour was $245 \mathrm{~m}$ for the geological settings and mining conditions of the Daliuta coal mine, with the mining heights of the working face and the width of the coal pillars being normally 7.0 and $20 \mathrm{~m}$, respectively. The less the elastic zone width was, the more the plastic zone width was, resulting in more serious land subsidence. It could also be quantitatively proved by pressure characteristics in tail areas during different stages as discussed before. In tail areas, P1 for No 130,135 and 140 support during stage 2 was much more than that during stage 1 (Table 3). The severe incidents including roof collapse and coal-wall rib spalling occurred in tail area of working face during stage 2. Under these conditions, the average SWC was decreased from 11.6-9.07\% during stage 1 and was greatly decreased from $11.5-7.34 \%$ during stage 2. For SC, it was decreased from $19.8 \mathrm{kPa}$ to $10.8 \mathrm{kPa}$ during stage 1 . SC before mining during stage 2 was only $10.5 \mathrm{kPa}$, it was found a less decrease to $8.24 \mathrm{kPa}$ after mining.

It was reported that underground mining had significant negative impacts on SWC at small spatial scale (the Daliuta Coal Mine) from 2001 to 2015 using an improved thermal inertia model with a long-term series of Landsat TM/OLI data (Wang et al., 2017), which was consistent with our findings. It indicated that underground mining was a primary cause for the drying trend of the mining area in semi-arid regions for the areas with decreasing trend of SMC mainly locating in the mining area (Wang et al., 2017). The possible reasons were that the underground mining activities damaging the rock-soil body (Bian et al. 2010) and causing the dramatic decrease of groundwater level (Lei et al. 2010).

\section{Conclusion}

This study proved that SWC, SC and soil porosity were greatly decreased, while bulk density and dry density were increased by coal mining during stage 2 in 2014. In comparison, coal mining did not influence organic matter, internal fraction angle, and D1 and D2 percent very much. SC was positively correlated to

Page 8/13 
SWC before and after mining, and SWC was a sensitive index that decided SC. The difference of pressure characteristics in tail areas of working face was large for two stages. The P1 during stage 2 was significantly greater than that during stage 1 , with severe roof collapse and coal-wall rib spalling incidents.

Comparison between two sites showed that both SWC and SC were decreased for the two stages by coal mining. The average bulk density and dry density after mining were less than those before mining during stage 1 in 2013, opposite to those during stage 2 in 2014 . The strong relationships between SC and SWC, and D1 and D2 percent were found in 2013 and 2014. Coal mining subsidence increased the cumulative probability to reach the same value of SWC and SC in 2013 and 2014. However, different conclusions were obtained for organic matter and internal fraction angle between 2013 and 2014.

The cover depth between two sites produced different elastic and plastic zone widths, which was quantitatively proved by pressure characteristics in tail areas of working face. The larger SWC decrease in site 2 during stage 2 might be mainly attributed to the higher pressure. The possible reasons were that the higher pressure would damage rock-soil body more seriously and cause the decrease of groundwater level more larger.

The impacted SWC decrease indicated a much dryer soil column for vegetation, while the impacted SC decrease indicated a much more serious erosive soil column. Mining company should take measures to control mining intensity to diminish soil destruction, reclaim the physically damaged land and restore the vulnerable ecological environment induced by coal mining. This study presented a quantitative evidence of the disturbance on soil physical quality indices between different underground mining intensity in semi-arid region of western China.

\section{Declarations}

\section{Acknowledgements}

The work was supported by "the Fundamental Research Funds for the Central Universities" (No. 2017XKQY072), "the Open Research Fund of Jiangsu Key Laboratory of Resources and Environmental Information Engineering, CUMT" (No. JS201808) and "2019 Xuzhou Science and Technology Plan Project" (No. KC19212).

\section{References}

1. Arvidsson J, Keller T (2011) Comparing penetrometer and shear vane measurements with measured and predicted mouldboard plough draught in a range of Swedish soils. Soil Tillage Res 111(2):219-223. doi:10.1016/j.still.2010.10.005

2. Bian Z, Inyang HI, Daniels JL et al (2010) Environmental issues from coal mining and their solutions. Mining Science Technology (China) 20(2):215-223. doi:10.1016/S1674-5264(09)60187-3

3. Bian ZF, Miao XX, Lei SG, Chen SE, Wang WF, Struthers S (2012) The challenges of reusing mining and mineral-processing wastes. Science 337:702-703. doi:10.1126/science.1224757

4. Dexter AR (2004) Soil physical quality Part 1. Theory, effects of soil texture, density, and organic matter, and effects on root growth. Geoderma 120:201214. doi:10.1016/j.geoderma.2003.09.004

5. Fan CC, Su CF (2008) Role of roots in the shear strength of root-reinforced soils with high moisture content. Ecol Eng 33(2):157-166. doi:10.1016/j.ecoleng.2008.02.013

6. Gao W (2014) Study on the width of the non-elastic zone in inclined coal pillar for strip mining. Int J Rock Mech Min Sci 72:304-310. doi:10.1016/j.jirmms.2014.09.013

7. Gentle JE (2009) Computational Statistics. Springer. ISBN 978-0-387-98145-1

8. Hao H (2015) Study on Mechanism of Intense Strata Behaviors along the Empty Side of Fully Mechanized Coal Face with Super Great Mining Height in Shallow Buried Coal Seam. China University of Mining and Technology, Xuzhou

9. He G, Yang L, Ling G, Jia F, Hong D (1991) Mining's subsidence. Xuzhou: China University of Mining and Technology Press, 81-82 (in Chinese)

10. He MC, Xie HP, Peng SP, Jiang YD (2005) Study on rock mechanics in deep mining engineering. Chinese Journal of rock mechanics engineering 24(16):2803-2813

11. Hemmat A, Aghilinategh N, Sadeghi M (2010) Shear strength of repacked remoulded samples of a calcareous soil as affected by long-term incorporation of three organic manures in central Iran. Biosys Eng 107(3):251-261. doi:10.1016/j.biosystemseng.2010.08.009

12. He Y, He X, Liu Z, Zhao S, Bao L, Li Q et al (2017) Coal mine subsidence has limited impact on plant assemblages in an arid and semi-arid region of northwestern china. Ecoscience 24:1-13. doi:10.1080/11956860.2017.1369620

13. Heras MM, las., Martín LM, Nicolau JM (2009) Effect of vegetation cover on the hydrology of reclaimed mining soils under Mediterranean-Continental climate. Catena 77:39-47. doi:10.1016/j.catena.2008.12.005

14. Heras MM, las., Espigares T, Martín LM, Nicolau JM (2011) Water-related ecological impacts of rill erosion processes in Mediterranean-dry reclaimed slopes. Catena 84:114-124. doi:10.1016/j.catena.2010.10.010

15. Huang Y, Tian F, Wang Y, Wang M, Hu Z (2014) Effect of coal mining on vegetation disturbance and associated carbon loss. Environmental Earth Science 73:2329-2342. doi:10.1007/s12665-014-3584-Z

16. Jing Z, Wang J, Zhu Y, Feng Y, Jing Z, Wang J et al (2018) Effects of land subsidence resulted from coal mining on soil nutrient distributions in a loess area of china. J Clean Prod 177:350-361. doi:10.1016/j.jclepro.2017.12.191

17. Johnson CE, Grisso RD, Nichols TA, Bailey AC (1987) Shear measurement for agricultural soils: a review. Transaction of ASABE 30:935-938. doi:10.13031/2013.30502 
18. Koolen AJ, Kuipers H (1983) Agricultural soil mechanics. In: Advanced Series in Agricultural Sciences, vol 13. Springer-Verlag, Berlin, (241 pp.)

19. Krümmelbein J, Raab T (2012) Development of soil physical parameters in agricultural reclamation after brown coal mining within the first four years. Soil Tillage Res 125:109-115. doi:10.1016/j.still.2012.06.013

20. Kuter N, Dilaver Z, Gul E (2014) Determination of suitable plant species for reclamation at an abandoned coal mine area. Int J Min Reclam Environ 28(5):268-276. doi:10.1080/17480930.2014.932940

21. Lei S, Bian Z, Daniels JL, Xiao HE (2010) Spatio-temporal variation of vegetation in an arid and vulnerable coal mining region. Mining Science Technology (China) 20(3):485-490

22. Léonard J, Richard G (2004) Estimation of runoff critical shear stress for soil erosion from soil shear strength. Catena 57:233-249. doi:10.1016/j.catena.2003.11.007

23. Liu H, Deng K, Lei S, Bian Z (2015) Mechanism of formation of sliding ground fissure in loess hilly areas caused by underground mining. International Journal of Mining Science Technology 25(4):553-558. doi:10.1016/j.ijmst.2015.05.006

24. Li ZW, Zhang GH, Geng R, Wang H (2015a) Rill erodibility as influenced by soil and land use in a small watershed of the loess plateau, china. Biosys Eng 129:248-257. doi:10.1016/j.biosystemseng.2014.11.002

25. Li ZW, Zhang GH, Geng R, Wang H, Zhang XC (2015b) Land use impacts on soil detachment capacity by overland flow in the loess plateau, china. Catena 124:9-17. doi:10.1016/j.catena.2014.08.019

26. Li Z, Xu J, Yu S, Ju J, Xu J (2018) Mechanism and prevention of a chock support failure in the longwall top-coal caving faces: A case study in Datong coalfield, China. Energies 11(2):288

27. Masoud SS, Parviz M, Ebrahim Y (2016) Optimizing and slope determination of final wall for Maiduk Mine with consideration of destabilizer factors. International Journal of Mining Science Technology 26(3):501-509

28. Mukhopadhyay S, Maiti SK, Masto RE (2013) Use of Reclaimed Mine Soil Index (RMSI) for screening of tree species for reclamation of coal mine degraded land. Ecol Eng 57:133-142. doi:10.1016/j.ecoleng.2013.04.017

29. Price DG (2009) De Freitas, M.H., ed. Engineering Geology: Principles and Practice. Springer. p. 450. ISBN 3-540-29249-7

30. Qiu L, Bi Y, Jiang B, Wang Z, Zhang Y, Zhakypbek Y (2019) Arbuscular mycorrhizal fungi ameliorate the chemical properties and enzyme activities of rhizosphere soil in reclaimed mining subsidence in northwestern China. Journal of Arid Land 11(1):135-147. doi:10.1007/s40333-018-0019-9

31. Reynolds B, Reddy KJ (2012) Infiltration Rates in Reclaimed Surface Coal Mines. Water Air Soil Pollution 223:5941-5958. doi:10.1007/s11270-012-13302

32. Ristović I (2010) Environmental Risks to Air, Water and Soil Due to the Coal Mining Process. NATO Science for Peace and Security Series-C. In: Environmental Security, Understanding and Managing Threats to the Environment in South Eastern Europe. Springer, Chap. 13, pp 251-264

33. Wang J, Qin Q, Hu S, Wu K (2016) A concrete material with waste coal gangue and fly ash used for farmland drainage in high groundwater level areas. J Clean Prod 112:631-638. doi:10.1016/j.jclepro.2015.07.138

34. Wang Y, Bian Z, Lei S, Zhang Y (2017) Investigating spatial and temporal variations of soil moisture content in an arid mining area using an improved thermal inertia model. Journal of Arid Land 9(5):712-726. doi:10.1007/s40333-017-0065-8

35. Wilson MG, Sasal MC, Caviglia OP (2013) Critical bulk density for a Mollisol and a Vertisol using least limiting water range: Effect on early wheat growth. Geoderma 192:354-361. doi:10.1016/j.geoderma.2012.05.021

36. Xiao L, Bi Y, Du S, Wang Y, Guo C (2019) Effects of re-vegetation type and arbuscular mycorrhizal fungal inoculation on soil enzyme activities and microbial biomass in coal mining subsidence areas of Northern China. Catena 177:202-209. doi:10.1016/j.catena.2019.02.019

37. Yang D, Zhang Y, Chen X (2019) Effect of coal mining on soil nitrogen distribution in semi-arid mining area of western China. Journal of Environmental Engineering Landscape Management 27(3):163-173. doi:10.3846/jeelm.2019.10795

38. Yang DJ, Bian ZF, Lei SG (2016) Impact on soil physical qualities by the subsidence of coal mining: A case study in Western China. Environ Earth Sci 75(8):652. doi:10.1007/s12665-016-5439-2

39. Yang Y, Erskine PD, Zhang S, Wang Y, Bian Z, Lei S (2018) Effects of underground mining on vegetation and environmental patterns in a semi-arid watershed with implications for resilience management. Environ Earth Sci 77(17):605. doi:10.1007/s12665-018-7796-5

40. Zang Y, Wang J, Ding G, Gao Y, He X, Yan L, Ren Y (2010) Variation of physico-chemical properties of aeolian sandy soil at coal mining subsidence and its evaluation. Acta Pedol Sin 47(2):262-269

41. Zhu W, Xu J, Xu G (2017) Mechanism and control of roof fall and support failure incidents occurring near longwall recovery roadways. J South Afr Inst Min Metall 117(11):1063-1072. doi:10.17159/2411-9717/2017/v117n11a11

42. Zhu W, Chen L, Zhou Z, Shen B, Xu Y (2019a) Failure propagation of pillars and roof in a room and pillar mine induced by longwall mining in the lower seam. Rock Mech Rock Eng 52(4):1193-1209

43. Zhu W, Qi X, Ju J, Xu J (2019b) Mechanisms behind strong strata behaviour in high longwall mining face-ends under shallow covers. J Geophys Eng 16(3):559-570. doi:10.1093/jge/gxz027

\section{Figures}




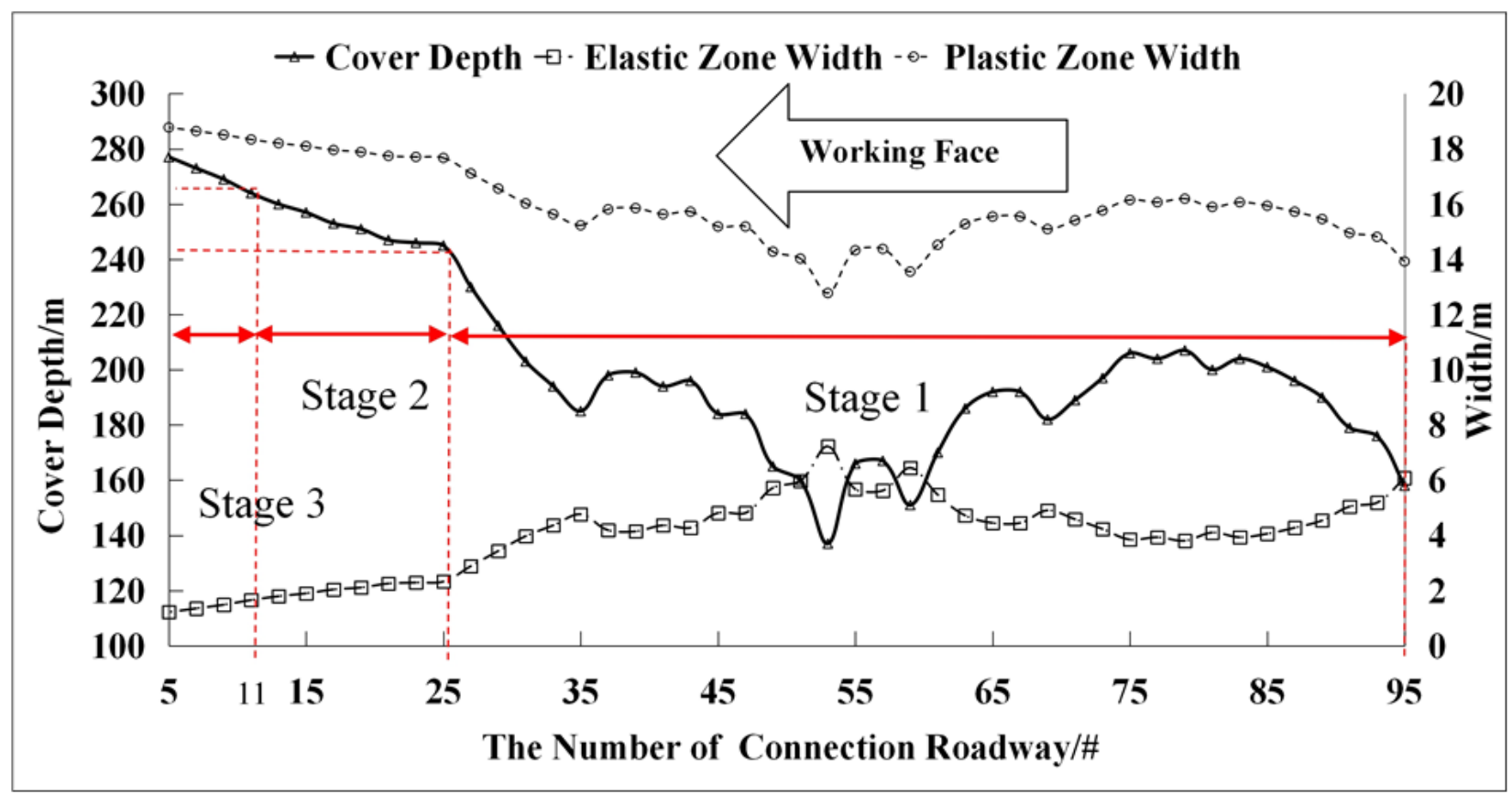

Figure 1

The relationships between cover depth and elastic and plastic zone widths for longwall No. 52303 during different strata behaviour stages

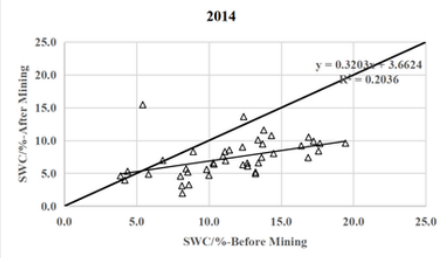

(A)

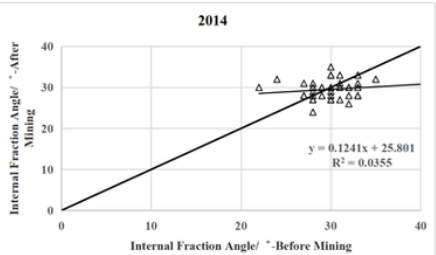

(D)

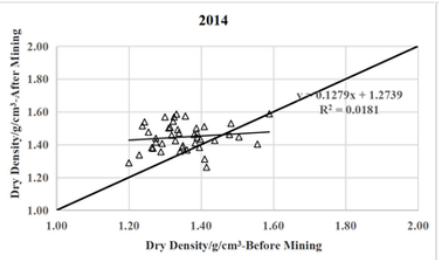

(G)

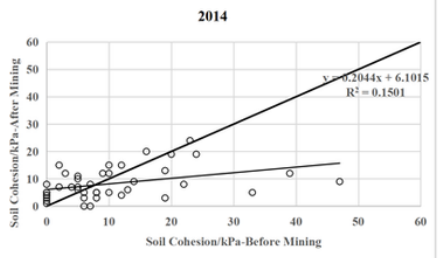

(B)

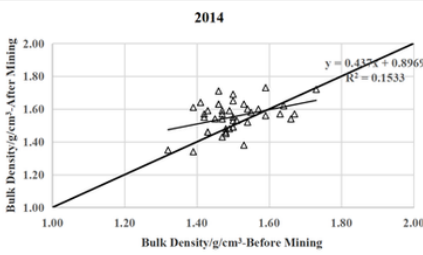

(E)

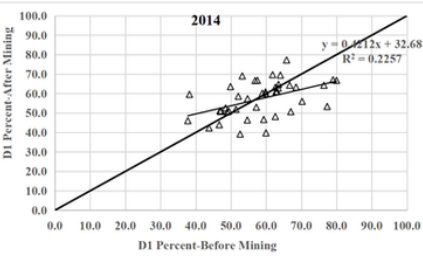

(H)

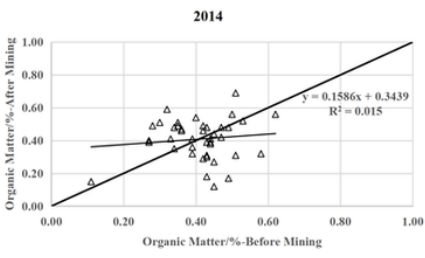

(C)

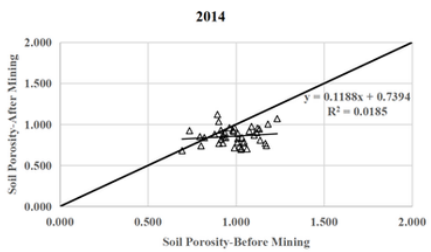

(F)

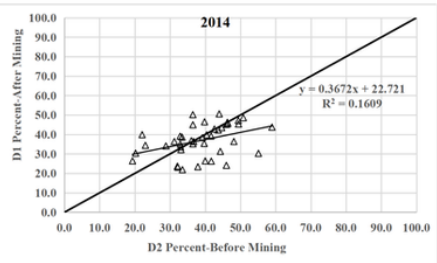

(I) 
The comparisons of soil physical quality indices before and after mining during stage 2 in 2014

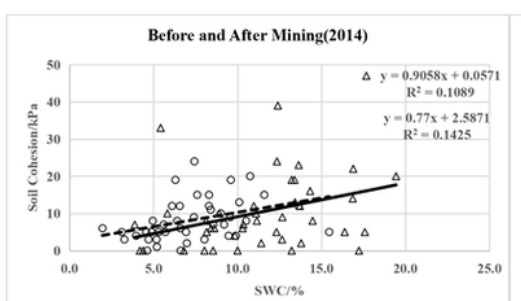

(A)

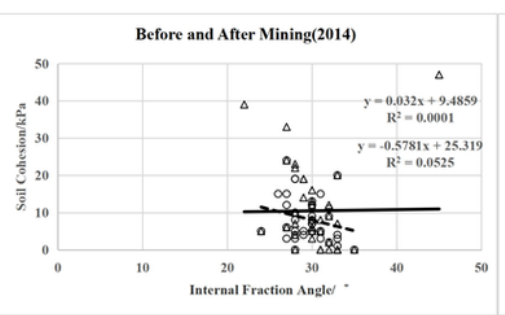

(B)

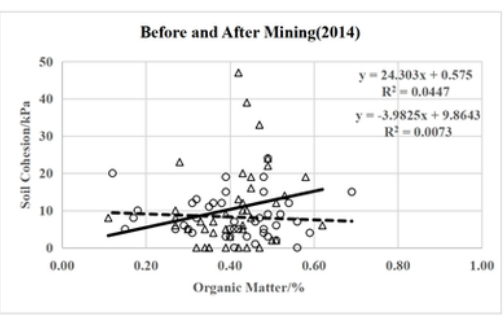

(C)

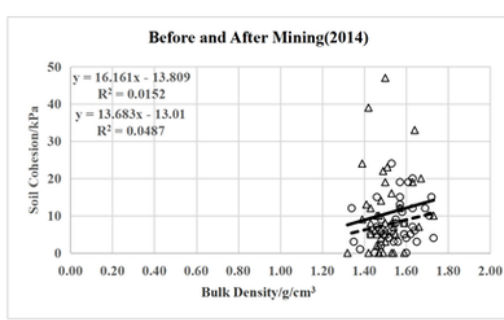

(D)

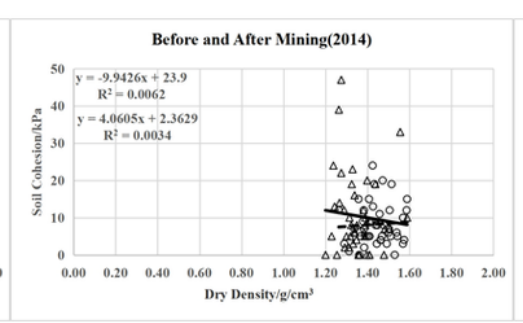

(E)

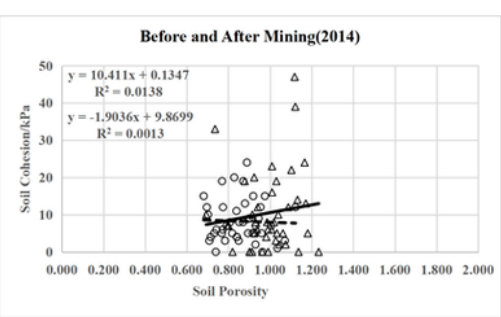

(F)

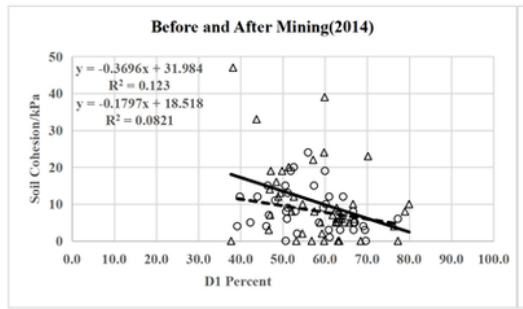

(G)

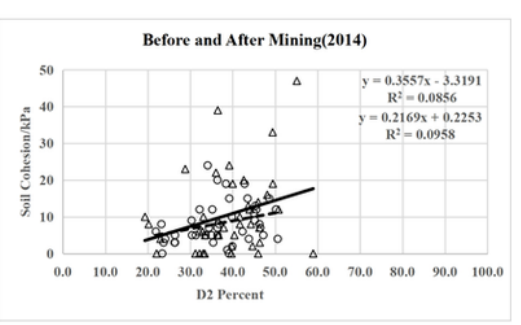

(H)

\section{Figure 3}

The relationships between SC and other indices before and after mining during stage 2 in 2014

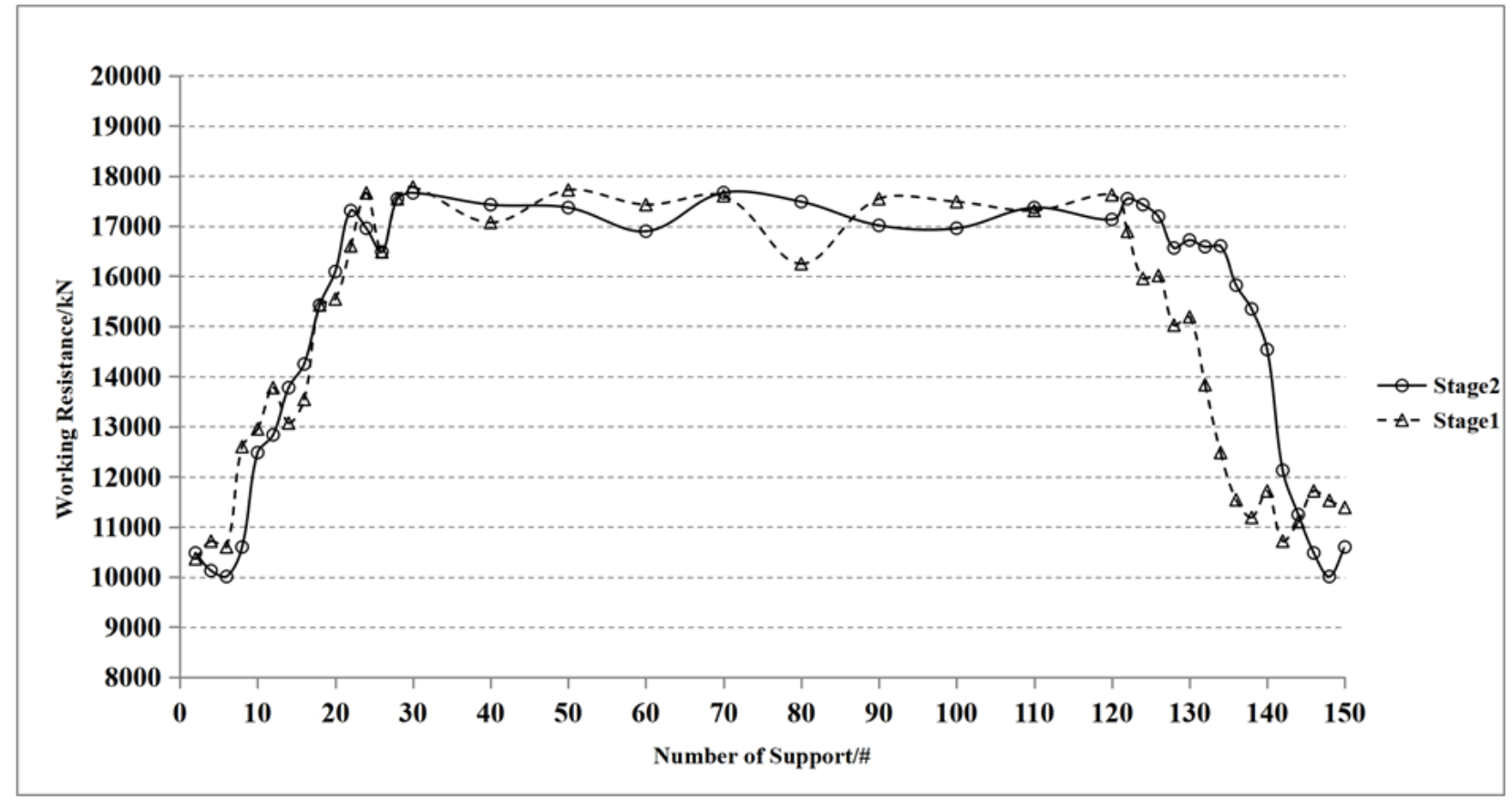


The whole comparison of support resistances between stage 1 and 2 (Zhu et al. 2017)

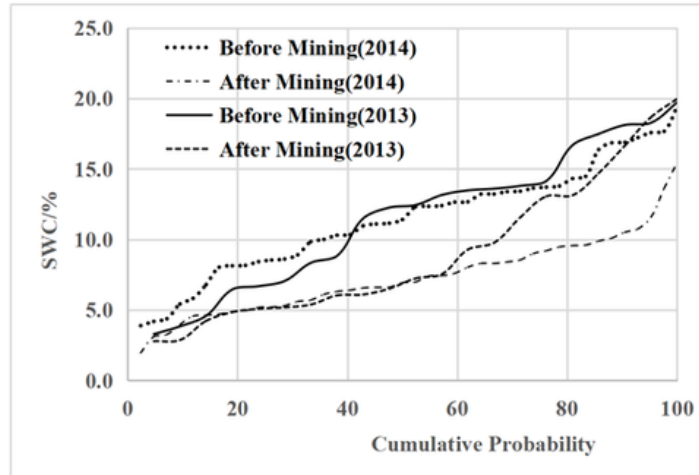

(A)

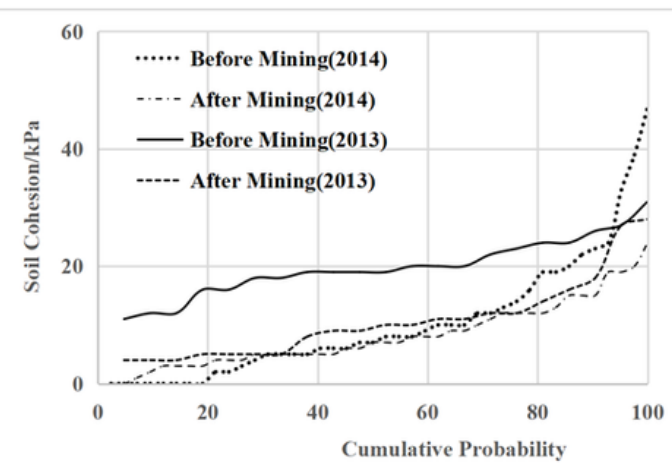

(B)

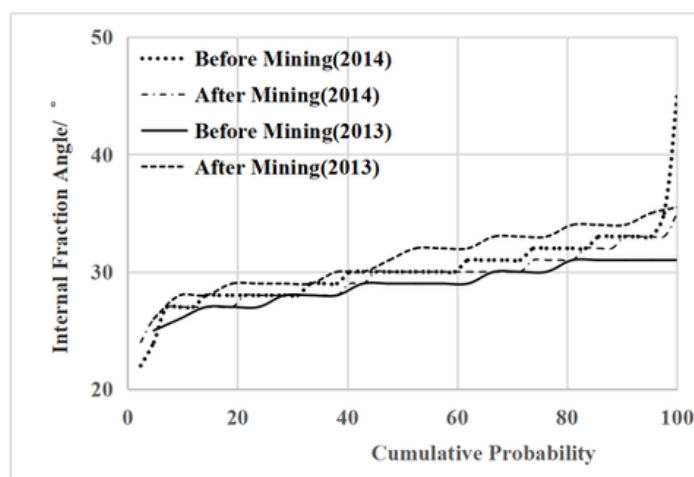

(C)

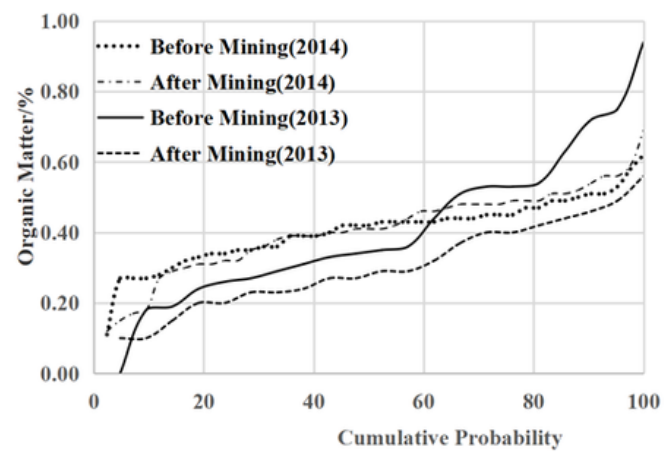

(D)

\section{Figure 5}

The cumulative probability of soil cohesion, SWC, internal fraction angle, and organic matter before and after mining in 2013 and 2014

\section{Supplementary Files}

This is a list of supplementary files associated with this preprint. Click to download.

- SupplementalMaterials1.doc

- SupplementalMaterials2.doc 